\title{
A Pécsi Egyházmegye hitoktatóinak helyzete és jövốképe
}

A vallás átalakulása, a vallásosság hagyományos formáinak visszaszorulása általános trend a keresztény kulturális alapokra épülő nyugati társadalmakban. Ez a folyamat sokrétú, gyakran ellentmondásos: a tradicionális elemek átalakulnak, új formában kelnek életre; gyengül a régi rituálék gépies megőrzését előtérbe helyező külsődleges vallásosság, ugyanakkor erősödik a személyes döntésen alapuló, belső elkötelezettséget igénylő aktivitás szerepe (Tomka M. 2000: V. 2.). Közben a vallás egyéb alrendszerek feletti integrátor-szerepe megszúnt. A vallás már nem egyértelmú és nem az egyetlen természetes értelemadó közeg a modern világ válaszokat kereső embere számára (Kamarás 2003: 13-39). A vallásos ismeretek és értékek átadása - a pluralista társadalom kihívásainak hatására - professzionalizálódik. Ebben a munkában - a papság mellett - kiemelt szerep hárul egy fontos közvetítő rétegre, a hitoktatókra. Tanulmányunk középpontjában a Pécsi Egyházmegyében tevékenykedő katolikus felekezetű hitoktatók életkörülményeinek vizsgálata áll egy kulcsszavakkal előhívott asszociációkra építő kutatás eredményei alapján. ${ }^{1}$

Magyarországon - ahogy a volt szocialista blokk országaiban általában jellemző - a fenti változások összekapcsolódtak a centralista politikai struktúrák által hozott döntések következményeivel (Tomka M. 2003: 9-27.). Míg a szocialista időszakban az államhatalom tudatos egyházellenes politikája felgyorsította a szekularizációt (Horváth 2007: 176-187.), addig a rendszerváltást követő időszakban az egyházi intézményrendszer újjászervezése lehetőséget biztosított az aktívabb társadalmi jelenlétre (Ragadics 2007a: 188-192.). Az átalakulás következményeként a korábban népegyházi szerepben lévő történelmi egyházak számára kiemelten fontos, hogy képesek legyenek a vallásos értékrend hatékony és hiteles képviseletére (Tomka F. 1999: 9-24.).

A vallási szervezetek kezében lévő intézményrendszer (templomok, plébániák, parókiák hálózata mellett egészségügyi, oktatási és szociális intézmények) fenntartása feladat és teher, ugyanakkor komoly lehetôség is az egyházak reprezentánsai számára. Alkalmas arra, hogy jelen legyenek a szekularizált társadalomban, s elérjék annak releváns tagjait. Az egyházi jelenlétet a szükségletek is megalapozzák: az állami, önkormányzati ellátórendszer, valamint a civil szféra gyengeségei olyan ûrt eredményeztek (különösen a szociális szektorban), amelynek betöltésére a történelmi egyházak képesek - elsősorban értékrendjük és hagyományaik miatt (Ragadics 2007b: 65-71.).

1 A vizsgálat módszerében a nyitott kérdéseket felhasználó kérdőíves kutatásokkal adekvát. 


\section{Hitoktatók a mai magyar társadalomban}

A történelmi egyházak munkájában sajátságos szerep hárul a hitoktatókra - elsősorban az adott felekezethez kapcsolódó értékek és normák átadása, közvetítése terén. II. János Pál pápa hitoktatásról szóló enciklikája (Catechesi tradendae 1979) alapján: „Az Egyház tudja, hogy legjobb erőit kell bevetnie a hitoktatásba, nem kímélve sem fáradságot, sem gondot, sem anyagi áldozatokat..." A magyar katolikus hitoktatás kerettantervének bevezetője is feltételezi: „,...a hittanárok és hitoktatók hitoktatásra felkészített, megfelelő teológiai, pedagógiai és a kateketikai ismeretekkel rendelkező, élő hitú katekéták..." (1996: 4-5.)

A magyarországi hitoktatók élethelyzetében, munkájában ugyanakkor számos ellentmondás is érvényesül. Munkavégzésük helye nagyfokú heterogenitást mutat. Az egyházi fenntartású intézményeket kivéve önkormányzati, alapítványi fenntartású óvodákban, iskolákban folytatják tevékenységüket a fenntartó engedélyével, így gyakran vendégként vannak jelen az intézményben és a tantestületben. A vezetôi kontroll többnyire nem érvényesülhet közvetlen módon felettesük, a területért felelős plébános jellemző túlterheltsége miatt.

Az általuk oktatott tárgy világnézetet ad át, értékrendet közvetít (a belsô viszonyulás, az elkötelezettség fontosabb az átadott tudásanyagnál), így speciális módszereket igényel: kiemelten fontos a hitoktató személyes példája, személyisége és hozzáállása. A tantárgy sajátosságaiból erednek a számonkéréssel kapcsolatos dilemmák is. Más tárgyak esetében a leadott tananyag elsajátításának kényszerét a rendszeres számonkérés, mérés alapozza meg. A hittan esetében ez a lehetôség / kényszer csak az egyházi iskolák esetében jelentkezik, más esetekben ez a kontroll-eszköz hiányzik a munkafolyamatból (kreativitásra ösztönözve a hitoktatót). Köztes szerepük alkalmanként élesen jelenik meg: többségük világiként, laikusként tevékenykedik, ugyanakkor az egyház hivatalos intézményrendszerét (sokak szemében a klérust) képviselik a gyermekek, szülők és más tárgyakat oktató kollégáik előtt. Az éves rendszerességgel megrendezésre kerülő továbbképzésen és lelkigyakorlaton kívül kevés lehetőségük adódik arra, hogy tapasztalataikat, napi problémáikat megosszák más hitoktatókkal, hittanárokkal. A fenti sajátságok miatt kiemelten fontos minden olyan vizsgálat, amely feltárja a hitoktatók speciális helyzetét, problémáit és lehetőségeit.

\section{Kutatás a Pécsi Egyházmegye hitoktatóinak körében}

A Pécsi Egyházmegye gyakorló hitoktatói körében végzett vizsgálatunk célja elsősorban az volt, hogy megismerjük a gyakorló hitoktatók, hittanárok munkavégzéssel, munkahelyi környezettel kapcsolatos attitúdjeit, terveit és elvárásait. A kutatást egy, a Pécsi Püspöki Hittudományi Főiskolán meghirdetett kutatószeminárium² ke-

2 A kutatást végzô csoport tagjai: Ragadics Tamás (oktató), Kovácsné Gál Katalin, Nagyné Gál Mária, Somodi Imre, Tutti Tibor, Ujhelyi Csilla Katalin. 
retei között végeztük, így az is fontos volt, hogy a vizsgálattal új módon létesítsünk hidat a képzőhely és a munkaerópiacon jelenleg aktív korábbi hallgatók között a hatékonyabb képzés érdekében.

A mintavételre egy nyitott kérdéseket tartalmazó, asszociációkat, véleményeket előhívó, önkitöltős kérdőív felhasználásával került sor 2011 novemberében. A kérdőíveket a Pécsi Egyházmegye gyakorló, heti rendszerességgel oktató katekétái töltötték ki önkéntesen. Vizsgálatunk a mintavétel hiányosságai miatt (nem valószínúségi, a hitoktatás helyére nézve nem reprezentatív) csupán egy nagyobb, országos vizsgálatot megalapozó előzetes tesztelésnek tekinthető, amelynek eredményei és tapasztalatai irányadóak lehetnek egy szélesebb körú kutatás előkészítéséhez. Ezzel együtt a Pécsi Egyházmegyében a gyakorló hitoktatók kb. 25-30\%-a szerepelt a mintában (48 fô). Felvettünk háttérváltozókat is (hitoktatás helyszíne, oktatott korcsoportok, a hitoktató életkora, képzettsége stb.) ezek azonban a válaszadók alacsony száma és a mintavétel módja miatt nem relevánsak.

Nyitott kérdéseinket egy egyszerú, a hitoktatók munkakörülményeivel kapcsolatos SWOT-analízis kialakításnak céljával a következő módon fogalmaztuk meg:

- Milyen örömei, sikerei voltak / vannak munkája során? Mire büszke? Mi a jó ebben a munkában? Miért érdemes hitoktatóként tevékenykedni?

- Milyen problémái, nehézségei vannak munkája során? Mi hátráltatja munkájának eredményességét?

- Milyen tervei, igényei vannak a jövőre nézve (hivatás)? Saját szakmai fejlődése szempontjából milyen lépéseket tart fontosnak? Ön - ha lehetősége lenne - milyen területeken változtatna a hatékonyabb katekézis érdekében? - Mit gondol (milyen változásokra számít) a hitoktatással, a munka külső feltételeivel kapcsolatban a jövőre nézve?

\section{Hitoktatás: öröm és büszkeség}

A hitoktatók többnyire az elsó kérdésre válaszoltak a legterjedelmesebben. Ez örvendetes tény, mert objektíve azt jelzi, hogy egyáltalán vannak örömök, sikerek ebben a hivatásban, és feltételezhetóen ezekből van több, nem pedig a kudarcokból, nehézségekből. Szubjektíve pedig azt, hogy a hitoktatók - és ez nem kevésbé fontos - hivatásuknak inkább örömeit, mintsem nehézségeit látják.

Közel sem meglepő módon a hitoktatók legnagyobb sikere munkájuk során az, hogy Istenhez vezethetik a gyermekeket, hitet ébreszthetnek bennük, és vezethetik őket a hit útján. Ilyen jellegú válaszok az esetek nagy hányadában fordultak elő.

A második leggyakrabban előforduló sikerélmény, örömforrás számukra az, hogy a gyermekek érdeklődnek a keresztény hit kérdései iránt, és lelkesen vesznek részt az órákon. Sokan válaszoltak úgy, hogy számukra önmagában pozitív, hogy gyerekekkel foglalkozhatnak, és hogy szeretetet adhatnak nekik és kaphatnak tőlük.

A válaszadók majd' harmadánál fogalmazódott meg sikerélményként az, hogy a gyermekeket a hitoktatók bevezették az egyházi közösségbe. Értve ez alatt azt, 
hogy a gyermekek szentségekhez járulnak (gyónás, elsőáldozás, bérmálás), szentmisére járnak, részt vesznek különböző egyházi programokon (pl. hittantábor), illetve hogy sikerült kialakítani keresztény ifjúsági csoportokat.

Pozitívumként értékelhetô az is, hogy a hittanosokon keresztül a szülőket, a családot is evangelizálni lehet.

Fontos tényezô a hitoktatók munkájukkal való elégedettségében, hogy olyan hivatást végeznek, amelyet igazán fontosnak tartanak, amelyben mély értelmet látnak, és amelyben „Isten munkatársaiként” tekinthetnek magukra.

Hat válaszadó szerint hivatásuk végzése közben nem csak ôk igyekeznek a rájuk bízottakat Isten felé vezetni, hanem ôk maguk is növekszenek hitükben, spirituális elmélyültségükben.

Végül néhány válaszadó számára örömet, sikert, büszkeséget jelent az, hogy hittanos tanítványai jól szerepelnek a hittanversenyeken, az iskolai rendezvényeken, és egyéb tantárgyak esetében is a jó tanulók közé tartoznak.

Ezenkívül tíz egyéb válasz is született, amely a fenti kategóriákba nem volt besorolható. Ez azért örvendetes, mert azt tanúsítja, hogy a hitoktatásban - a hitoktatók szerint - sokféle örömforrás, sikertényezó rejlik, illetve hogy ezeket a hitoktatók észre is veszik, felismerik. Ezek közül csak egyet szeretnénk kiemelni, azért mert elsôre talán nagyon hízelgó a hitoktatásra vonatkozóan, ám - feltéve, hogy a válaszadónak igaza van - komoly kritikát fogalmaz meg a formális iskolai neveléssel kapcsolatban: „Azért érdemes ezen a területen tevékenykedni, mert sok esetben a hittanóra az egyetlen alkalom, ahol a gyermek szeretetet kap."

Csupán egyetlen fó válaszolt úgy, hogy nem volt sikere és öröme munkájában.

\section{Problémák, konfliktusok}

Ha a második kérdésre adott válaszok alapján azokat a tényezóket vizsgáljuk, amelyek a hitoktatóknak munkájukban nehézséget okoznak, akkor azonnal szembeötlik a szülői érdektelenség mint legsúlyosabb probléma. A válaszadók közel fele említi, hogy a hittanórai és a családi nevelés között nincs kongruencia, mert a családi vallásgyakorlás sokszor hiányzik vagy formális. A szülők nem mutatnak példát gyermekeiknek a vallásos életre vonatkozóan. Az, hogy a gyermek eltérő normarendszerrel találkozik otthon és a hittanórán, nagy nehézség elé állítja a hitoktatót.

A második legnagyobb probléma az óraegyeztetés. A válaszadók harmada szerint a hatékony hitoktatást lehetetlenné teszi, hogy nincs a hittannak órarendi helye, így csak nulladik órában vagy késő délután (egy válaszadó szerint 4 óra után!) lehet megtartani. Ráadásul a tanulók jelentékeny része délután fakultatív foglalkozásokon (szakkör, edzés stb.) vesz részt, amelyek sok esetben ütköznek a hittannal, mert az iskola a délutáni programok megszervezésekor nem mindig van tekintettel a hitoktatásra. Így a hittanosok gyakran hiányoznak a hittanóráról, vagy legalábbis kénytelenek egyik foglalkozásról a másikra rohanni. Ezzel függ össze a gyerekek fáradtsága is, amely a válaszadók szerint a harmadik legfőbb akadály (tíz válaszban jelent meg ez a téma): ez nem is csoda, ha a hittanórára csak a tanítási nap végez- 
tével kerülhet sor. A fáradt, pihenésre, kikapcsolódása vágyó tanulókat sokszor érthetô módon - kevéssé köti le a hittan.

A nehézségek sorában a negyedik a megfelelő tankönyvek, oktatási segédanyagok, szemléltető eszközök hiánya.

A válaszadók közül hatan problémásnak ítélték a hitoktatók és a papság viszonyát: szerintük a papság nem támogatja kellően a hitoktatók munkáját. Még elszomorítóbb, hogy csupán egyetlen válaszadó mondta azt, hogy ennek oka az, hogy a papság is túlterhelt, a többiek szerint egyszerúen érdektelenségről van szó. A nehézségek sorrendjében közvetlenül ezután következik a hitoktató és a tantestület nem megfelelö kapcsolata.

Ugyanakkor látható, hogy a problémák forrását a hitoktatók nem csupán külsô tényezőkben, hanem önmagukban is keresik: néhány válaszadó saját korlátait (túlterheltség, rutin hiánya, megbecsültség hiánya, bún) is megnevezte, mint nehézséget.

Problémát jelent a tanulók érdeklődésének hiánya, a lemorzsolódás, az alacsony tanulói létszám is. Nem megoldott a hitoktatásból kikerülők utógondozása, nincsenek erre alkalmas ifjúsági csoportok.

A problémák rangsorában csak az utolsó helyen jelenik meg a hitoktatók alacsony fizetése (három fő említette). (Ezen kívül két válaszadó említést tett az anyagi források hiányáról, ám válaszukból nem derült ki egyértelmúen, hogy saját honoráriumukról vagy a katolikus egyház által a hitoktatásra fordított összegekrôl pontosabban azok alacsonyságáról - van szó.) Mindenestre megállapítható, hogy a hitoktatók többsége nem a materiális jellegú problémákban látja a hitoktatás legfőbb kerékkötőit (kivétel ez alól a taneszközhiány).

A fentieken kívül egyéb problémákat is megjelölt a válaszadók. Például: magas csoportlétszám, a nem hittanos gyerekek rossz példája, gyakorlati jellegú továbbképzések hiánya, a szekuláris világszemlélet stb.

\section{Tervek, igények, lehetôségek}

A harmadik kérdésre adott válaszaikban a hitoktatók egyaránt kitértek arra, hogy ők maguk miben kívánnak változni, illetve az egyházmegyének miben kellene változtatnia a hatékonyabb katekézis érdekében. A válaszoknak ez a két típusa szorosan összefügg. Hogy példaként egy jellemző választ említsünk: a továbbképzéseken való részvétel egyrészt a hitoktató egyéni hajlandóságán múlik, másrészt azon, hogy az egyház egyáltalán szervez-e továbbképzéseket. Ugyanígy kétoldalú dolog a hitoktatók és az egyházszervezet, illetve a hitoktatók egymás közti kapcsolatainak szorosabbra szövése. Ilyen megfontolások alapján nem látjuk indokoltnak a „lehetőségek" kategória szétválasztását egyéni illetve a szervezetben rejlő lehetőségekre.

A válaszadók többsége gondolta úgy, hogy a továbbképzésben való részvétel lehetőséget jelent a katekézis eredményesebbé tételére. Egyesek felsőfokú teológiai tanulmányokat kívánnak folytatni a Pécsi Püspöki Hittudományi Főiskolán, vagy éppenséggel már folytatnak is. Mások részt vesznek hitoktatói továbbképzéseken vagy legalábbis az igényük megvan rá. Vannak, aki szakirányú továbbképzéseken 
(pl. mentálhigiéné) vesznek részt / kívánnak részt venni. Egyesek az egyházi rend felvételét is tervezik (diakonátus). Ismét mások önállóan, autodidakta módon képzik magukat. Elmondható tehát, hogy a tárgyi és szakmódszertani tudásnak a hitoktatók nagy jelentőséget tulajdonítanak. Az viszont rendkívül meglepő, hogy - bár hitoktatókról van szó - a lelki fejlődés, a spiritualitásban való elmélyülés fontossága nem jelent meg ilyen súllyal a válaszokban: csupán három válaszadó említi. (Illetve néhányan tesznek említést arról, hogy Jézus Krisztus, Isten kegyelme stb. által válik valaki jó katekétává.)

A második legfontosabb lehetőséget a hitoktatók a hitoktatás módszertani megújításában látják: új tankönyvekkel, a figyelmet jobban megragadó tanítási módszerekkel, technikai eszközökkel stb. Ebből az látszik, hogy hitoktatók jelentékeny részére jellemző egyfajta „technokrata” szemlélet, amely szerint a katekézis hatékonyságának javítása technikai kérdés (is): informatikai eszközökkel, új tankönyvcsaládokkal, új oktatási stratégiákkal megoldható. Pedig ennél jóval többről van szó. Erre érzett rá az a hat válaszadó, akik szerint a hittant „tantárgyatlanítani” kell: a formális ismeretközlés helyett a tanulók lelki épülésére, a merev tanórai keretek helyett a bensôségességre kell helyezni a hangsúlyt. Valóban: bár nagy szükség van a korszerú szakmódszertanra és modern taneszközökre, a hitoktatás megújítása sokkal inkább a hittan mint tantárgy gyökeres átértelmezésétôl várható.

Hat válaszban jelent meg a hitoktatók közötti folyamatos kapcsolattartás, együttmúködés fontossága. Ennek pozitív hozadéka - a kölcsönös segítségen kívül - az állandó tapasztalatcsere is lehetne.

Ugyanennyien jegyezték meg, hogy a hitoktatást szoros kapcsoltban kell szemlélni és végezni a családpasztorációval, szülőkatekézissel. Ez egyrészt feltétele, másrészt következménye a sikeres hitoktatásnak. Feltétele, mert a gyermekek közt végzett hatékony katekézis nehezen képzelhető el, ha a tanuló a családban nem találkozik a hittanórán átadott értékekkel. Következménye, mert a gyermeken keresztül a hitoktató a szülőt is evangelizálni tudja. Ebben lát egy fontos lehetőséget a hitoktatók egy része.

Részben összefügg ezzel, hogy néhány válaszadó a hitoktatók tevékenyégét radikálisan átértelmezve úgy gondolja, hogy - természetesen a gyermekek iskolai hitoktatását sem zárójelbe téve - a felnőttek katekézisére kellene nagyobb hangsúlyt helyezni. Ez összhangban van a katolikus egyház eredeti, ókereszténykori hagyományával, illetve mai gyakorlatával, mely szerint az évszázadokon át gyakorolt formális, ismeretközlő, „kötelező” iskolai hitoktatás helyett a kereszténységet érett fejjel és tudatos elhatározással választó felnőttek katekézise preferálandó (Keszeli é. n.: 6-20.).

Négy válaszadó gondolja úgy, hogy a hitoktatás hatékonyságának emeléséhez javítani kell a hitoktatók erkölcsi és anyagi megbecsültségén. Ugyanennyien vélekednek úgy, hogy szorosabbra kell fúzni a hitoktatók kapcsolatát az egyházszervezettel mikroszinten (plébánia) és makroszinten (egyházmegye) egyaránt.

A hitoktatók örömteli kreativitását jelzi, hogy számos további, a fenti kategóriákba nem sorolható lehetôséget is megfogalmaztak a hitoktatás eredményesebbé tételére: pl. szentségek vételére való alaposabb felkészítés, iskolakápolna kialakítása, zene alkalmazása a katekézisben, cigánypasztoráció felkarolása stb. Sôt nagyszabású, az 
egyházi hierarchia szerepét átértékelő javaslatok is megfogalmazódtak, mint például a laikusok nagyobb részvétele az egyház életében, illetve bázisközösségek kialakítása. Az egyik válaszadó pedig - bár nem zárhatjuk ki, hogy részben iróniával állunk szemben - teljesen szakítana a hitoktatás eddigi gyakorlatával: „A hatékonyabb katekézis érdekében beszüntetném a hitoktatást, és tanúságtevő életet élnék."

\section{Mit hoz a jövő?}

A negyedik kérdésre adott válaszok mutatják a legnagyobb varianciát: a válaszadók közel 60 különböző választ fogalmaztak meg. Ezek a visszajelzések annyira sokfélék, hogy kategóriákba sorolni őket szinte lehetetlen. Ezért a következőkben úgy fogjuk osztályozni a válaszadókat, hogy optimistán vagy pesszimistán látják a jövôt.

A válaszadók többsége optimistán szemléli a jövőt, és pozitív irányú változásokra számít. Az optimista jövőképpel rendelkezők közé soroltuk azokat is, akik elégedettek jelenlegi munkakörülményeikkel, ezért nem tartanak szükségesnek változásokat. 8 fő kifejezetten pesszimistán látja a jövőt, elsősorban saját jövőjét. A pesszimisták közé soroltuk azokat is, akik azt írták ugyan, hogy nem számítanak változásokra, de válaszaikból egyértelmúen kiderül, hogy negatívan látják a jövơt. 4 fő nem számít változásokra, 5 fő nem tudja, mit várjon a jövőtől, 1 fő pedig nem válaszolt. A további 10 válaszadó többnyire óhajokat és elvárásokat fogalmazott meg anélkül, hogy nyilatkozott volna arról, bízik-e ezek megvalósulásában. Ezek a válaszadók tehát nem fogalmaztak meg egyértelmú (pozitív vagy negatív) jövőképet.

Az optimista válaszok között többször fordul elő a bizalom kifejezése az új pécsi püspök, Udvardy György személyében. Sokan gondolják úgy, hogy az új püspök tevékenységének köszönhetően rendezettebbek lesznek a Pécsi Egyházmegye viszonyai, ami pozitív hatással lesz a katekézisre is. Láthatjuk, hogy egy aktuális esemény - egy új főpásztor kinevezése - milyen jelentős hatással volt az egyházmegye hitoktatóinak közérzetére, jövôképére. Továbbá az optimisták közül többen remélik, hogy növekszik a hitoktatás, a hitoktatók erkölcsi és anyagi megbecsültsége, órarendi helyet kaphat a hittan, javul az együttmúködés a szülőkkel, pedagógusokkal és a papsággal, illetve új lehetőségek tárulnak fel a pasztorációban elsősorban a laikusok bevonásával.

A pesszimisták elsősorban a saját egzisztenciájukat féltik, leépítésektől, csökkenő gyermeklétszámtól és emelkedő kötelező óraszámtól tartanak, illetve nem remélik, hogy a hittan órarendi helyet kap.

\section{Összegzés}

A fenti eredmények - elsősorban az alacsony elemszám miatt - nem szolgálhatnak alapként messzemenő következtetésekhez, ugyanakkor érdemi információkat közölnek egy speciális, átmeneti és ellentmondásos helyzetben lévő pedagógusrétegrôl, ezáltal elősegítik a hitoktatókra jellemző élethelyzetek és problémák megértését. 
A vizsgálat során szerzett tapasztalatok lényegesek (támogatásul, megerôsítésül, iránymutatóul szolgálnak) a gyakran egymástól elszigetelten tevékenykedő hitoktatók, hittanárok, valamint a képzésükben érintett intézmények, oktatók számára is.

Eredményeink fontos visszajelzést jelentenek a munkahelyi környezet aktorainak, a hitoktatók tevékenységét irányító plébánosoknak és az egyházmegye oktatásszervezési feladatokat ellátó munkatársainak is. A gyermekek, fiatalok és idősebbek javára megvalósított hatékony hitoktatói hivatás komoly kooperációt igényel a fenti szereplők részérôl.

Vizsgálatunk közvetve hozzájárulhat egy nagyobb, a hitoktatók körében végzendő országos kutatás megalapozásához, amely eredményeivel támogathatja a hitoktatói pálya népszerúsítését a fiatalok körében, illetve alapul szolgálhat egy - a speciális körülményekhez és szükségletekhez igazodó -, a lemorzsolódás és kiégés megelőzését célzó hitoktatói életpályamodell kialakításához.

\section{Hivatkozott irodalom}

HoRvÁTH István (2007): A templomból a kultúrházba. In Varga Szabolcs-Vértesi Lázár (szerk.): Az 1945 utáni magyar katolikus egyháztörténet új megközelítései. Pécs, PPHF PEI, 176-187.

Kamarás István (2003): Kis magyar religiográfia. Pécs, Pro Pannonia.

KESZELI SÁNDOR (é. n.): Alapvető kateketika. Bevezetés a katekézis elméleti alapjaiba katekétáknak. Internet: http://www.gfhf.hu/contentviewer/getfile/filestore/downloads/konyvtar/keszeli/alapveto_kateketika.pdf, letöltve: 2012. 04. 20.

RAgadics TAmás (2007a): Egyházi alapú közösségépítés. In Varga Szabolcs-Vértesi Lázár (szerk.): Az 1945 utáni magyar katolikus egyháztörténet új megközelítései. Pécs, PPHF PEI, 188-196.

RAGADICS TAMÁs (2007b): A történelmi egyházak társadalmi szerepvállalása az Ormánságban. A Falu 1 (1), 65-71.

TOMKA FERENC (1999): Új evangelizáció. Egyházunk helyzete és feladatai az ezredfordulón. Budapest, Szent István Társulat.

Tomka Miklós (2000): Vallásszociológia. Internet: http://www.fil.hu/ uniworld/vt/szoc/tom-ka_1.htm, letöltve: 2012. 04. 20.

TOMKA MikLós (2003): Az ifjúság változó vallása nemzetközi összehasonlításban. In uô (szerk.): Ifjúság, értékek, vallás. Budapest, Faludi Ferenc Akadémia, 9-27.

Catechesi tradendae. Apostoli buzdítás a hitoktatásról (II. János Pál) (1979): Budapest, Szent István Társulat.

A Magyar Katolikus Hitoktatás Kerettanterve (1996): Eger, MKPK HB. 